\title{
Symphonia globulifera, a Widespread Source of Complex Metabolites with Potent Biological Activities
}

\author{
Authors \\ Yann Fromentin ${ }^{1}$, Kevin Cottet ${ }^{1}$, Marina Kritsanida ${ }^{1}$, Sylvie Michel ${ }^{1}$, Nicolas Gaboriaud-Kolar ${ }^{1,2}$, \\ Marie-Christine Lallemand ${ }^{1}$ \\ Affiliations \\ ${ }^{1}$ Laboratoire de Pharmacognosie, Université Paris Descartes, Sorbonne Paris Cité, Paris, France \\ 2 Department of Pharmacognosy and Natural Products Chemistry, Faculty of Pharmacy, University of Athens, Athens, Greece
}

Key words

- Symphonia globulifera

- Clusiaceae

ethnomedicine

- secondary metabolites

- biosynthesis

- biological activities received July 15, 2014

revised October 12, 2014

accepted Nov. 19, 2014

Bibliography

DOI http://dx.doi.org/

10.1055/s-0034-1396148

Published online January 15 ,

2015

Planta Med 2015; 81: 95-107

(c) Georg Thieme Verlag KG

Stuttgart · New York .

ISSN 0032-0943

\section{Correspondence}

Prof. Dr. Marie-Christine

Lallemand

Laboratoire de Pharmacognosie,

UMR CNRS 8638 COMETE

Université Paris Descartes

Sorbonne Paris Cité

4 avenue de l'Observatoire

75006 Paris

France

Phone: + 33153739693

Fax: +33140469658

marie-christine.lallemand@

parisdescartes.fr

\section{Abstract}

$\nabla$

Symphonia globulifera has been widely used in traditional medicine and has therefore been subjected to several phytochemical studies in the American and African continents. Interestingly, some disparities have been observed concerning its metabolic profile. Several phytochemical studies of S. globulifera have led to the identification of more than 40 compounds, including several poly-

\section{Introduction}

$\nabla$

Higher plants are known to be a rich source of various bioactive compounds [1], some of which have found practical applications in traditional medicine [2]. Symphonia globulifera L.f. has been widely used in traditional medicine to fight against various disorders such as parasitic disease $[3,4]$ or body pain [5]. Extracts of this plant have shown very good biological activities against several pathologies, opening a vast field of research towards the identification of complex metabolites. Since the first publication in 1992 [6] describing some polycyclic polyprenylated acylphloroglucinols (PPAPs) from S. globulifera as HIV inhibitors, the interest for this plant and its bioactive compounds has been ever growing. Like the plants of the Garcinia genus, which also contain PPAPs [7], the plants of the species S. globulifera have emerged on both American and African continents, and show some morphological diversity through sites [8]. This morphological differentiation and the existence of some subfamilies and differences in country soil and climate have probably induced a variation in the metabolome and generated a pool of chemodiversity. The purpose of this review is to describe the botanical aspects, the ethnomedical uses, metabolites, and biogenesis, as well as the biological activities of all com- cyclic polyprenylated acylphloroglucinols. Biological evaluations have pointed out the promising biological activities of these secondary metabolites, mostly as antiparasitic or antimicrobial, confirming the traditional use of this plant. The purpose of this review is to describe the natural occurrence, botanical aspects, ethnomedicinal use, structure, and biogenesis, as well as biological activities of compounds isolated from this species according to their provenance.

pounds from this species depending on their provenance.

\section{Classification and Botanical Characteristics of Symphonia globulifera} $\nabla$

The family Clusiaceae (Guttiferae) comprises about 40 genera and more than a thousand species. The genus Symphonia includes 17 species [9]. S. globulifera is broadly distributed across the Neotropics and equatorial Africa. It is the only Symphonia species found outside Madagascar [10].

Some of the vernacular names of this plant are "manil marécage", "palétuvier jaune" (French Guiana), "barillo" (Guatemala, Honduras), "cerillo" (Costa Rica, Panama), "machare” (Colombia), "mani”, "paraman” (Venezuela), "mataki” (Surinam), "manni" (Guiana), "anany" (Brazil), and "brea-caspi” (Peru). S. globulifera plants are generally tall trees (in general more than $15 \mathrm{~m}$ high) with opposite leaves exhibiting characteristic aerial roots and producing a bright yellow latex. The flowers are red with a red staminal column and black anthers and organized as a sympodium. Fruits are drupes $(4-5 \mathrm{~cm})$, ovoid, or globular. Seeds are intensively red inside [10-12].

This species is also characterized by important morphological variations, which seem to be de- 
Table 1 Traditional use of S. globulifera in Africa and South America.

\begin{tabular}{llll}
$\begin{array}{l}\text { Localization } \\
\text { Africa }\end{array}$ & Part of plant & Preparation method & Therapeutic use \\
\hline $\begin{array}{l}\text { Gabon } \\
\text { South Uganda }\end{array}$ & Bark & Decoction & Scabies [15] \\
\hline $\begin{array}{l}\text { South Uganda } \\
\text { Cameroon }\end{array}$ & Bark & Decoction & Coughs, intestinal worms, prehepatic jaundice, fever [4] \\
\hline $\begin{array}{l}\text { Nigeria } \\
\text { South America }\end{array}$ & Leaves & Sap burned like incense & Chasing away evil spirits [4] \\
\hline Panama & Leaves & Decoction & Antiparasitic [17] \\
\hline Brazil & Decoction & Skin disease, malaria, diabetes [16] \\
\hline Brazil & Leaves & Cataplasm & \\
\hline Colombia & Latex & Plaster & Body pain, skin ailments [5] \\
\hline & Bark & Infusion or with soda & To get pregnant, pulled muscles, fractures [18] \\
\hline
\end{tabular}

pendent of its ecological distribution [8]. Indeed, at least three varieties exist, var. angustifolia Maguire, var. macoubea Vesque, and var. major Diels $[8,13]$, and a small number of supposed subspecies such as Symphonia sp1. However, none of these differences have been yet considered sufficient to merit splitting into more than one species.

Phylogenetic analyses have demonstrated that marine dispersal played a primary role in the migration and establishment of $S$. globulifera in the Neotropics. The regional populations were genetically isolated through the Pleistocene and earlier [9]. In Central Africa, S. globulifera survived the Pleistocene glacial periods in a few major shelters, essentially centered on mountainous regions close to the Atlantic Ocean [14]. The capacity for adaptation in different geographical and climate conditions contributed to the survival and to the genetic and morphological diversity of the species.

\section{Ethnomedicine}

$\nabla$

Medicinal plants have been playing an important role in providing health care to a large section of the population, especially in developing countries. S. globulifera has been used for the treatment of several disorders, mainly in Africa and South America.

\section{Africa}

The African traditional medicine proposes an accurate use of local plants though poorly scientifically studied. Concerning $S$. globulifera, preparations are mainly decoctions, with applications ranging from serious disorders, such as scabies, to spiritual remedies ( Table 1 ).

Ethnopharmaceutical studies presented in $\bullet$ Table 1 were performed on a large panel of medicinal plants (around 120 plants). The establishment of this panel was based on several criteria such as the use defined by an ethnic group, an area of the country, or the country in general. For instance, the Gabonese studies focused on the use of medicinal plants relating to the single Masango ethnic group [15], chosen because it is one of the few ethnic groups in Gabon that have kept medical practices as part of its cultural heritage. Therefore, among the plants used by the Masango, decoctions of S. globulifera bark are produced to cure the serious problem of scabies.

More recently, studies from Nigeria [16] and Uganda [4] describe the use of S. globulifera not only in terms of ethnicity but also depending on the region of occurrence: Akwa Ibom State (Nigeria) and the Sango bay area (Uganda). In Nigeria, leaves of S. globuli- fera are used as a decoction and are applied on the body to treat skin disease, which is the largest application followed by malaria and diabetes. Other traditional uses in Nigeria are described in the literature to treat erective problems, venereal diseases, or wounds using the fruits and leaves of S. globulifera [19]. However, information regarding the type of preparation was not described; the data has been discarded from $\odot$ Table 1 .

The Ssegawa's study [4] highlights the medicinal plants used by 13 villages in three subcounties surrounding the Sango bay ecosystem in the Rakai district, Central Uganda. A questionnaire has been distributed to collect data on local plant names, uses, parts used, and modes of preparation and administration. From this study, it appears that the $S$. globulifera biological activities are dependent on the vegetal parts. Thus, the bark extract presents broad applications ranging from treating coughs and prehepatic jaundice to fever and intestinal worms. A different application has been observed for the sap extract, which is used for spiritual application to chase away evil spirits. While this traditional use of S. globulifera has been proven to exist, the obvious lack of scientific meaning makes its difficult to understand.

Leishmaniasis and others protozoal diseases are a plague without a sustainable cure, which dramatically affects the African continent. Considering the great potential of Cameroon in terms of biodiversity, traditional knowledge, and practice, Lenta et al. [17] undertook an ethnopharmacological survey on medicinal plants used against protozoal diseases in this country. Data were collected by contact and interviews with local traditional healers in the Ndé and Mifi divisions of the West Province of Cameroon. The selected plants, including S. globulifera, were collected and further evaluated for their in vitro antiprotozoal activity and cytotoxicity ( Table 2).

Overall, mainly decoctions of bark or leaves of $S$. globulifera are used in the African traditional medicine, indicating the presence of polar metabolites as the main source of activity. The results of the study presented in $\odot$ Table $\mathbf{2}$ may participate in understanding the traditional use and strengthen the presence of active metabolites in polar extracts. Remarkably, South American traditional remedies are slightly different and present other panels of applications.

\section{South America}

The traditional use of S. globulifera in South America is not as widespread as in the African continent. Literature resources highlight its use principally in Panama, Brazil, and Colombia ( Table 1). Similar to Africa, the bark, which is the most used part of the plant, is prepared as a decoction or infusion. 


\begin{tabular}{|c|c|c|c|}
\hline \multicolumn{4}{|l|}{ S. globulifera from Cameroon } \\
\hline Local name: Kebanti & Place of collection: Bangangté & Voucher No. 32192/HNC & Part used: leaves \\
\hline Methanolic extract & & $\mathrm{IC}_{50}(\mu \mathrm{g} / \mathrm{ml})$ & SI \\
\hline Plasmodium falciparum & & $4.1 \pm 0.5$ & $12.75^{*}$ \\
\hline Trypanosoma cruzi & & $>30$ & $1.5^{*}$ \\
\hline Trypanosoma brucei rhodesiense & & $11.5 \pm 0.5$ & $4.5^{*}$ \\
\hline Leishmania donovani & & $2.1 \pm 0.8$ & $24.9^{*}$ \\
\hline Cytotoxicity & & $52.3 \pm 5.6$ & \\
\hline
\end{tabular}

Table 2 In vitro activity of S. globulifera leaf methanolic extract.

* SI (selectivity index): ratio of cytotoxic activity on L-6 cells to antiparasitic activity

In Panama, the need to explore the ethnobotanical resources in order to develop appropriate programs for their agricultural, medical, pharmaceutical, silvicultural, and commercial use is increasing [5]. Moreover, since massive deforestation has been accelerated, there is a high emergency to collect information and try to save the renewable botanical resources in order to develop appropriate programs in silviculture and agriculture. For this purpose, a study was performed on the local plants. S. globulifera was part of the study, and its fresh latex was shown to be used and applied as a cataplasm against skin ailments and body pain. The Brazilian Amazon region has a considerable coastline [18]. In Pará State, for example, more than $1500 \mathrm{~km}$ of coastline extends from the Amazon River's estuary to the state of Maranhão, covered by mangroves and swamps, defined by abundant natural resources and great scenic beauty. As secondary vegetation, S. globulifera has been described in this mangrove area. It has been shown that the use of its latex favors pregnancy and is active against pulled muscles and fractures. The latex is thus used under a plaster form and is therefore easy to apply on bone fractures. Regarding the barks, they are prepared as an infusion or with soda against vaginal discharge.

In Colombia [3], the plants were collected in four different areas guided by local knowledgeable healers. S. globulifera was harvested on the Bajo Calima site. The decoction of the bark is traditionally rubbed on the skin for the treatment of cutaneous leishmaniasis.

In summary, the traditional uses of S. globulifera on both the African and American continents are specific but present some similarities. The application of cataplasm directly on the body to treat skin diseases or cutaneous leishmaniasis revealed the presence of polar molecules, which are attractive for cosmetic, dermatologic, and antiparasitic applications. Comparing the practices in both continents, the bark seems to contain the main active metabolites, while the leaves and fruits are poorly used. Finally, from all these surveys, a potent and promising antiparasitic activity of $S$. globulifera metabolites emerges.

\section{Secondary Metabolites}

\section{$\nabla$}

Secondary metabolites of $S$. globulifera are mainly PPAPs. Up to now, a total of 15 of them have been isolated from this species in addition to the xanthone derivatives of PPAPs: two oxy-PPAPs ( Table 3 and Fig. 1). In $\odot$ Table 3, each compound is described (name, plant part, and country of collection). It is worth noticing that most PPAPs and oxy-PPAPs described in the literature are numbered as a bicyclo[3.3.1]nonane-1,3,9-trione, although Ciochina et al. [20] numbered PPAPs as a bicyclo[3.3.1]nonane2,4,9-trione. The first numbering is the one that will be followed here. All the compounds are detailed in 0 Table $\mathbf{3}$ and described in subsections.

\section{Polycyclic polyprenylated acylphloroglucinols}

Even if three types of PPAPs are described (A, B, and C) [38], all the PPAPs characterized from $S$. globulifera belong to the type B family ( Fig. 1). All of them have been isolated from roots; however, guttiferone $\mathrm{A}(\mathbf{1})$ has also been isolated from leaves and seeds. To date and with the exception of the guttiferones $A(\mathbf{1})$ and $B(2)$, all isolated PPAPs have not been described in any other plant. Guttiferone B (2) has also been isolated from Garcinia oblongifolia and Garcinia cowa [32-34] and guttiferone A (1) from about ten other plant species like Garcinia livingstonei [35], Rheedia edulis [36], Garcinia macrophylla [37], Garcinia virgate [38], Garcinia brasiliensis [39]. As for many type B PPAPs, secondary cyclization has been observed, as illustrated with the presence of a dimethylpyran $(5,6,7,8,9,10,11,17)$ or furan moiety $(12,13)$ obtained from the epoxydation of a prenyl followed by a ring closure. Compounds 14 and 15 belong to the oxy-PPAPs category, cyclized PPAPs into xanthones. To date, 14 natural type B oxy-PPAPs have been reported, three have been obtained via chemical reactions or biotransformation from garcinol (47) [40] and guttiferone A (1) [41]. The biogenesis of oxy-PPAPs is discussed later in this review.

\section{Polyhydroxylated polyprenylated xanthones and maclurin}

Besides these PPAPs, maclurin (36), 21 polyhydroxylated polyprenylated xanthones, and benzophenone have been isolated from S. globulifera ( $\bullet$ Fig. 2 and Table 3). Prenylated xanthones, such as the well-known gambogic acid, are extensively represented in the Clusiaceae and Hypericaceae families [42,43]. These molecules have been isolated from several plant parts of $S$. globulifera, such as heartwood, twigs, roots, seeds and leaves. Most of the compounds show side decoration-like prenylated moieties, which can later be involved in the formation of a dimethyldihydropyran core $(\mathbf{1 8}, \mathbf{2 0}, \mathbf{2 1}, \mathbf{2 3}, \mathbf{2 6}$, and $\mathbf{2 7})$. Only one dimer (20) resulting from the phenolic coupling has been isolated.

\section{Biflavonoids}

Another interesting group of natural products has been isolated and described from S. globulifera ( Fig. 3). The latter is a small number of biflavonoids comprising three members that could be depicted as the heterodimerization of apigenin $(39,40)$ or a luteolin (41) moiety on one hand, with a luteolin (39) or dehydroquercetin moiety $(\mathbf{4 0 , 4 1 )}$ on the other hand. They all present a junction between $\mathrm{C}-3$ and $\mathrm{C}-8$. To date, three biflavonoids have been isolated from the leaves and twigs of this plant. Biflavonoids are restricted to a few groups of plants and are commonly isolated from species of the Clusiaceae family. Morelloflavone (39) 
Table 3 Secondary metabolites isolated from S. globulifera.

\begin{tabular}{|c|c|c|c|c|c|}
\hline No. & Name & Plant part & Country & Molecular weight* & Ref. \\
\hline \multicolumn{6}{|c|}{ Polycyclic polyprenylated acylphloroglucinols and oxy-PPAPs } \\
\hline \multirow[t]{3}{*}{1} & Guttiferone A & seeds & Cameroon & 602.36 & [21] \\
\hline & & roots & Central African Republic & & {$[6]$} \\
\hline & & leaves & Cameroon & & [17] \\
\hline 2 & Guttiferone B & roots & Central African Republic & 670.42 & [6] \\
\hline 3 & Guttiferone C & roots & Central African Republic & 670.42 & [6] \\
\hline 4 & guttiferone D & roots & Central African Republic & 670.42 & [6] \\
\hline 5 & 14-Deoxy-7-epi-isogarcinol & root barks & French Guyana & 586.37 & [22] \\
\hline 6 & Symphonone A & root barks & French Guyana & 600.35 & [22] \\
\hline 7 & Symphonone B & root barks & French Guyana & 670.42 & [22] \\
\hline 8 & Symphonone C & root barks & French Guyana & 618.36 & [22] \\
\hline 9 & 7-epi-Coccinone B & root barks & French Guyana & 618.36 & [22] \\
\hline 10 & Symphonone D & root barks & French Guyana & 636.37 & [22] \\
\hline 11 & Symphonone E & root barks & French Guyana & 636.37 & [22] \\
\hline 12 & Symphonone F & root barks & French Guyana & 618.36 & [22] \\
\hline 13 & Symphonone G & root barks & French Guyana & 618.36 & [22] \\
\hline 14 & Symphonone H & root barks & French Guyana & 600.35 & [22] \\
\hline 15 & Symphonone I & root barks & French Guyana & 600.35 & [22] \\
\hline 16 & 7-epi-Garcinol & root barks & French Guyana & 602.36 & [22] \\
\hline 17 & 7-epi-Isogarcinol & root barks & French Guyana & 602.36 & [22] \\
\hline \multicolumn{6}{|c|}{ Polyhydroxylated polyprenylated xanthones and benzophenones } \\
\hline 18 & Globulixanthone C & root barks & Cameroon & 326.08 & [23] \\
\hline 19 & Globulixanthone D & root barks & Cameroon & 326.12 & [23] \\
\hline 20 & Globulixanthone E & root barks & Cameroon & 618.19 & [23] \\
\hline 21 & Gaboxanthone & seeds & Cameroon & 438.17 & [21] \\
\hline 22 & Globuliferin & seeds & Cameroon & 440.18 & [21] \\
\hline 23 & Symphonin & seeds & Cameroon & 438.17 & [21] \\
\hline 24 & Globulixanthone A & root barks & Cameroon & 324.10 & [24] \\
\hline 25 & Globulixanthone B & root barks & Cameroon & 380.16 & [24] \\
\hline 26 & Xanthone V1 & leaves & Cameroun & 394.14 & [17] \\
\hline 27 & Ananixanthone & bark & Brazil & 378.15 & [25] \\
\hline 28 & 1,7-Dihydroxyxanthone & heartwood & Uganda & 228.04 & [26] \\
\hline 29 & 1,5,6-Trihydroxyxanthone & heartwood & Uganda & 244.04 & [26] \\
\hline \multirow[t]{2}{*}{30} & 1,3,5,6-Tetrahydroxyxanthone & heartwood & Uganda & 260.03 & [26] \\
\hline & & twigs & Cameroon & 260.03 & [27] \\
\hline \multirow[t]{2}{*}{31} & Norathyriol & heartwood & Uganda & & [26] \\
\hline & & twigs & Cameroon & & [27] \\
\hline 32 & Symphoxanthone & heartwood & Uganda & 328.09 & [28] \\
\hline 33 & Globuxanthone & heartwood & Uganda & 312.10 & [28] \\
\hline 34 & Ugaxanthone & heartwood & Uganda & 328.09 & [29] \\
\hline 35 & Mbarraxanthone & heartwood & Uganda & 312.10 & [29] \\
\hline 36 & Maclurin & heartwood & Uganda & 262.05 & [30] \\
\hline 37 & Gentisein & twigs & Cameroon & 244.04 & [27] \\
\hline 38 & Globulixanthone E & twigs & Cameroon & 342.11 & [27] \\
\hline \multicolumn{6}{|c|}{ Biflavonoids } \\
\hline 39 & Morelloflavone & leaves & - & 556.10 & [31] \\
\hline \multirow[t]{2}{*}{40} & GB-2 & leaves & - & 574.11 & [31] \\
\hline & & twigs & Cameroon & & [27] \\
\hline 41 & GB3 & twigs & Cameroon & 590.11 & [27] \\
\hline
\end{tabular}

* Molecular weights are calculated

was also isolated from other species belonging to the Clusiaceae, such as G. livingstonei [35] or Garcinia xanthochymus [44].

\section{Methyl nervonate}

A last metabolite has been recently isolated and named methyl nervonate (42) by the authors [45]. It has been characterized in the anther oil of S. globulifera from Brazil ( Fig. 4). This fatty acid may have an important functional role in the pollination process. Harvesting location plays a role in the metabolic profile, especially for PPAPs present in the root bark extract. Indeed, Marti et al. [22] did not identify guttiferones A-D (1-4) described by Gus- tafson et al. [6], highlighting notable disparities in the metabolome of the species between those two continents (harvested in May 2006 and March 1988, respectively). The collection of different subspecies could eventually be considered the origin of the metabolic disparities. Moreover, such differences in the nature of major metabolites are uncommon, even for a single species growing in two different locations. As we pointed out, S. globulifera has a high rate of acclimatization and might adapt its defensive metabolites according to, for example, the microbial environment. However, there is a need to clearly report the phenomena, which requires further investigations. 


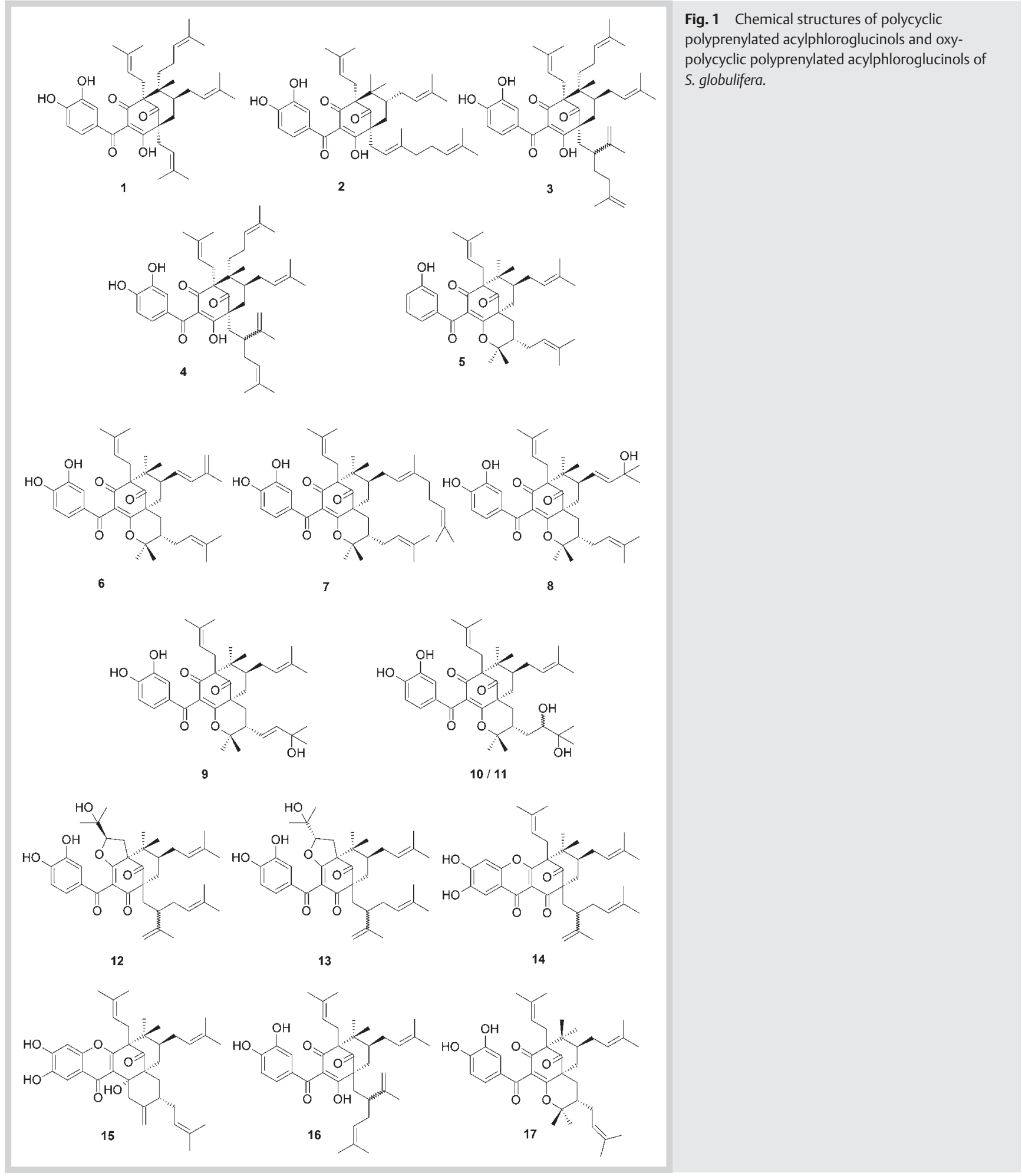

\section{Biosynthesis}

All the secondary metabolites isolated from S. globulifera have the same biosynthetic origin ( Fig. 5). The biosynthesis starts from shikimic acid to generate amino acids such as tyrosine or phenylalanine [46].

Phenylalanine is converted into cinnamic acid, by phenylalanine ammonia lyase (PAL) [47]. Cinnamic acid can then follow two different pathways to generate either biflavonoids or prenylated xanthones and PPAPs. Concerning biflavonoids, there is an early enzymatic hydroxylation to convert cinnamic acid into 4-hydroxy-coumaric acid $[48,49]$. A polyketide synthase generates then the phloroglucinol moiety of the chalcone [50]. A chalcone isomerase is responsible for the cyclization of the chalcone into the corresponding flavones $[51,52]$. Two hypotheses can be cited for the biflavonoids biosynthesis, the chalcone, or the flavonoid dimerization. Yamaguchi et al. [53] have highlighted the participation of some peroxidase enzymes to accomplish the dimerization of flavones into biflavonoids. Some biomimetic syntheses of 


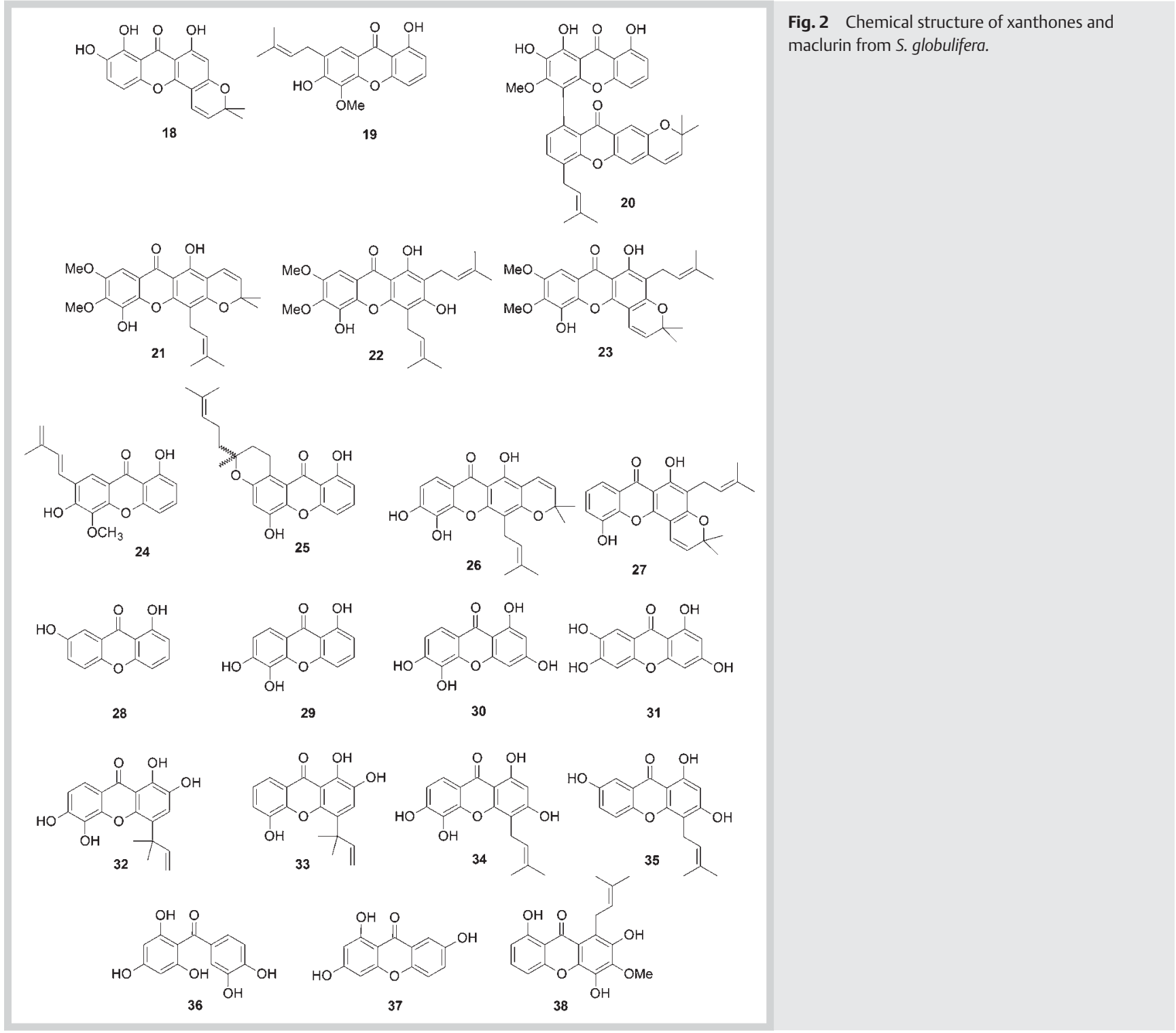<smiles>O=C1c2c(O)cc(O)cc2OC(c2ccc(O)cc2)C1Cc1c(O)cc(O)c2c(=O)cc(-c3ccc(O)c(O)c3)oc12</smiles>

39<smiles>O=C1c2c(O)cc(O)c(CC3c4c(O)cc(O)cc4OC3c3ccc(O)cc3)c2OC(c2ccc(O)c(O)c2)C1O</smiles>

40<smiles>O=C1c2c(O)cc(O)c(O)c2OC(c2ccc(O)c(O)c2)[C@@H]1O</smiles>

41
Fig. 3 Chemical structure of biflavonoides from S. globulifera.

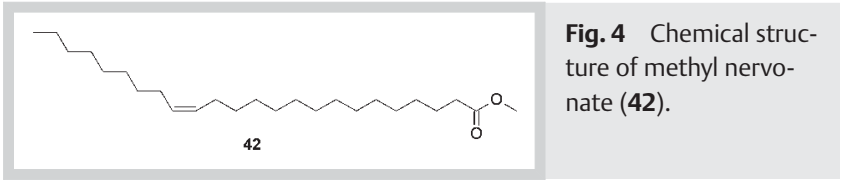

biflavonoids validate this hypothesis [54]. Dimers are generated from monomers in the presence of an oxidant (potassium ferricyanide), which is well known to be able to generate phenolic oxidative coupling.

The biosynthesis of xanthones and PPAPs also starts from phenylalanine being converted into a phenyl-CoA moiety, which is reduced into protocatechuic acid. It has been shown that coumaric acid, cinnamic acid, and phenylalanine were well incorporated 


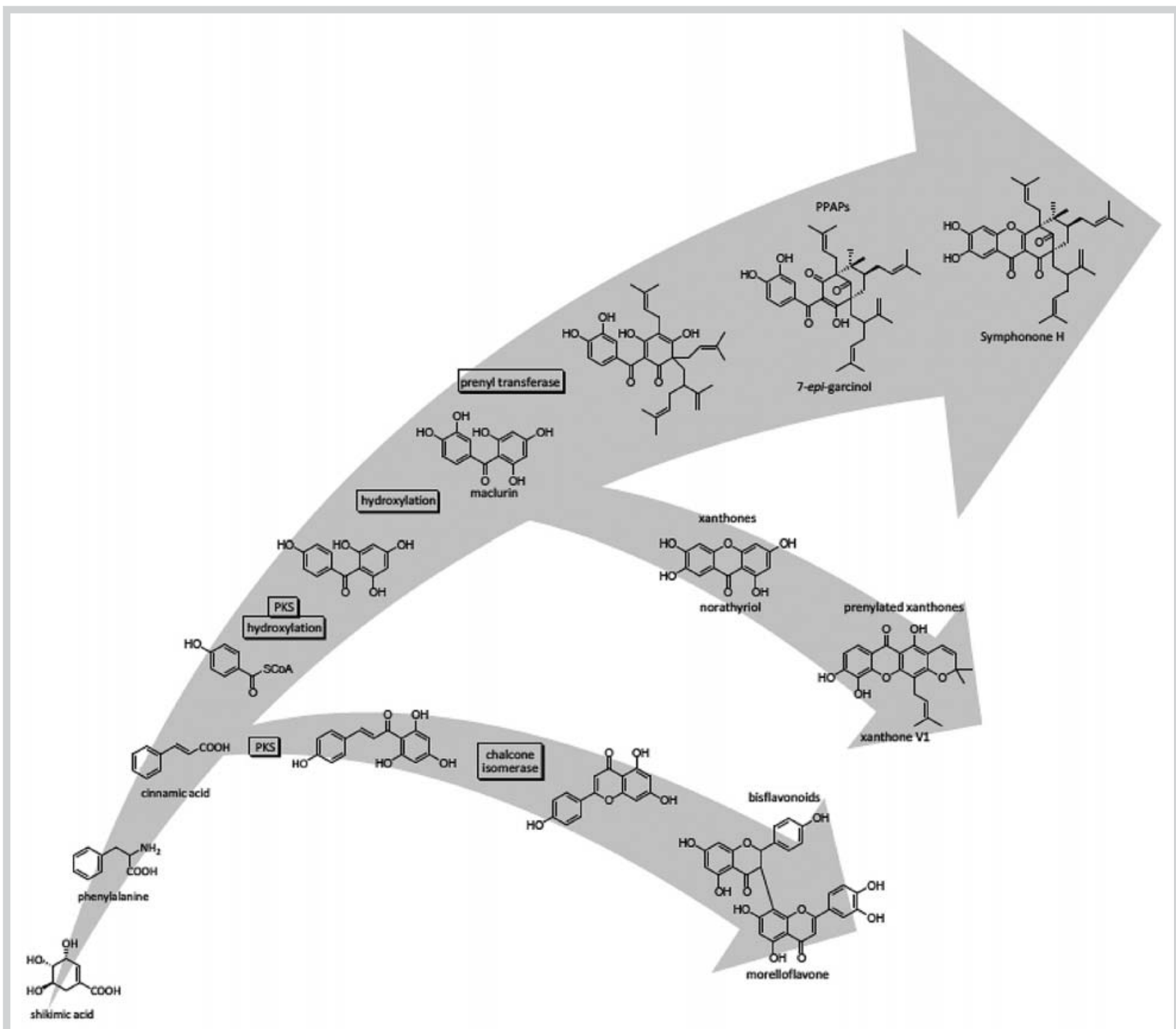

Fig. 5 Biosynthesis pathway of S. globulifera secondary metabolites.

during xanthone-labeled biosynthesis experiments. As for the flavonoids, this moiety is subjected to an enzyme-assisted hydroxylation to afford the catechol acyl-CoA, which is then taken in charge by a PKS to generate the phloroglucinol part. The latter is finally transformed in the polyhydroxylated benzophenone [55-58]. This polyhydroxylated benzophenone is the starting point of both prenylated xanthones and PPAPs.

This pathway is a major divergence between plants and bacteria/ fungi. Indeed, xanthones of the microorganism world are generally synthesized from full polyketides $[59,60]$. Peters et al. pointed out evidence of enzymatic participation in the xanthone synthesis from the polyhydroxylated benzophenone. The ring closure to generate the xanthone core is mediated via a P450 cytochrome and a xanthone synthase, and occurs through an oxidative coupling [61]. Atkinson and coworkers predicted the implication of a hydroxylated benzophenone for the xanthone biosynthesis through a phenol oxidative coupling [62]. As for the biflavonoids dimers, these compounds can be obtained using potassium ferricyanide as an oxidant. Further functionalization (hydrox- ylation, methoxylation, prenylation) occurs once this xanthone core (synthesis) is obtained.

The hypothetic PPAPs biosynthesis has already been described by Kumar et al. [7] in their review on Garcinia species (- Fig. 6). All compounds of this family ( 1 to 17 ) seem to be derived from maclurin (36), after being taken in charge by prenyl transferases. Several studies have been done on hyperforin [63-65] to elucidate the mechanism and the sequence of crucial steps. Prenylation occurs first on position 6 , then on position 4 , and finally one more on position 6 . The nine-membered ring is formed by a concerted mechanism where the next prenyl transfer involves an intramolecular activation and cyclization leading to the unique backbone. This reactivity was confirmed by some biomimetic syntheses [66]. In the presence of an oxidant, the prenylated acylphloroglucinol moiety can itself be cyclized to generate the bicyclo[3.3.1] nonane-9-one skeleton.

Further modifications can also be performed by the plant, such as additional prenylation, hydroxylation, condensation into tetrahydropyran, or condensation in a more complex cycle. Consider- 


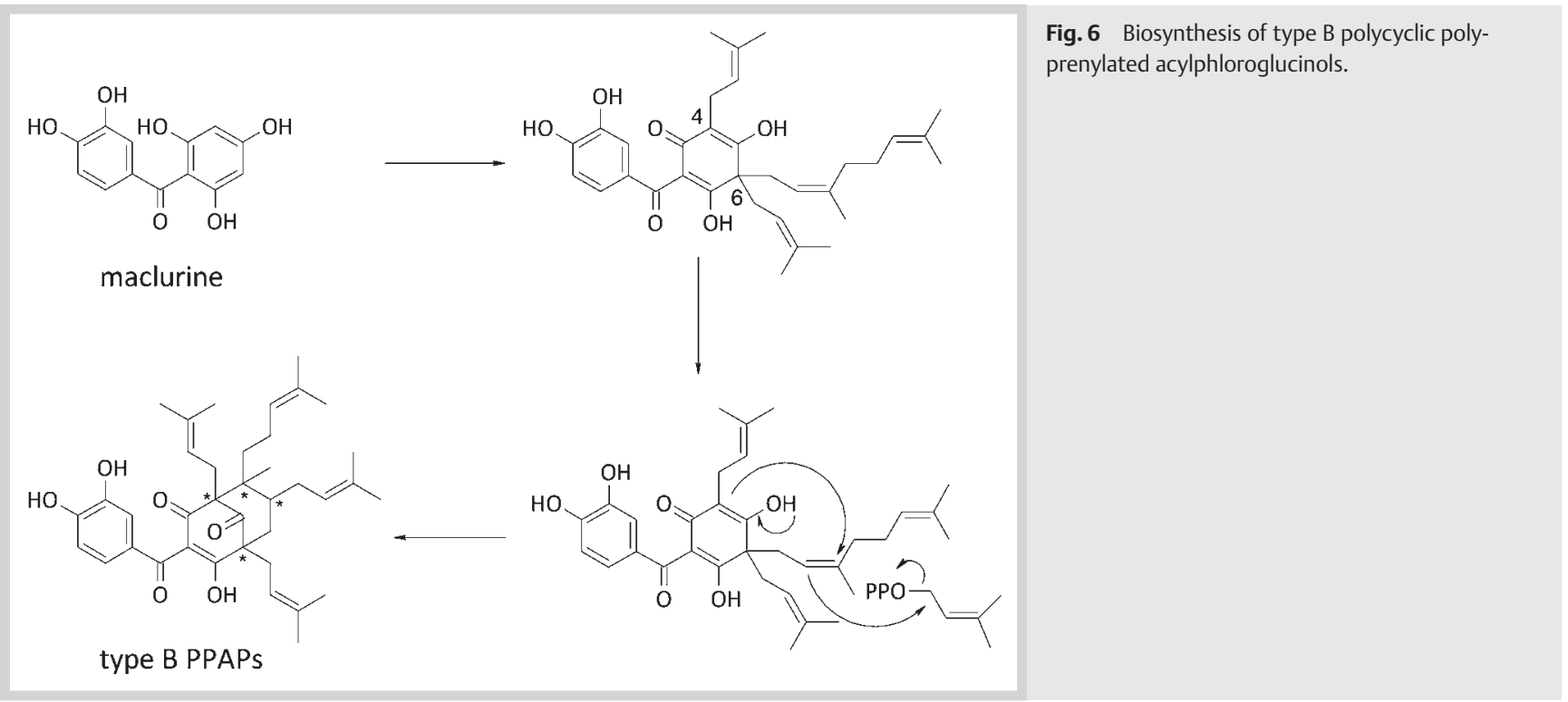

ing those side modifications and the different stereochemistry possibilities, S. globulifera is able to produce a number of different analogs.

Symphonone $\mathrm{H}$ (14) belongs to the oxy-PPAPs family present in the Garcinia genus. The biosynthesis of such compounds has been discussed by several authors. In 2008, Xu et al. identified two compounds structurally related, guttiferone L (43) and garciyunnanin B (44), in their study of G. yunnanensi and in the same organ (pericarp) [34]. As represented in $\bullet$ Fig. 7, the authors proposed a biosynthetic pathway for the conversion of guttiferone $\mathrm{L}$ (43) into garciyunnanin B (44). Their hypothesis involves the unique 3,4,6-trihydroxyphenyl skeleton converting into an intramolecular cyclization. The activation of the carbonyl in C-3 in enolate leads to the subsequent condensation on the $\mathrm{C}-16$ position with the loss of water and formation of the xanthone. Even if this cyclization mechanism is possible, guttiferone L (43) ( Fig. 7) is, to date, the only tri-hydroxylated type B PPAP isolated, while several other type of oxy-PPAPs (including trihydroxylated xanthones) have been found, suggesting another mechanism and thus a poor probability of this pathway.

In their recent study of thorelione A (45), N'guyen et al. [67] provided a mechanism involving a pseudo-Michael addition (๑ Fig. 7). Their hypothesis is based on the attack of the free doublet of the enol C-3 in the $\mathrm{C}-16$ position of the aromatic ring. The delocalization of the negative charge on the ketone followed by a return to aromaticity leads to the loss of a proton and the formation of the oxy-thorelione A (46).

The third mechanism ( $\odot$ Fig. 7) proposed by the Sang $[40,68]$ and Huang groups [33] involves a radical intermediate. The oxidation of the enolate to the enolate radical results in the formation of a $\mathrm{C}_{\mathrm{ar}}-\mathrm{O}$ bond. These fully conjugated compounds allow for the delocalization to the mono ketone form. The keto-enol equilibrium allows for the return on the most stable tautomer. The free rotation of the acyl then allows the formation of the angular (C1-C16) and linear xanthones (C3-C16) found in some other species such as G. indica [34].

This mechanism is supported by the Huang group, who used the oxidants 2,2-diphenyl-1-picrylhydrazyl (DPPH) or azo-bis-(isobutyronitril) (AIBN) ( Fig.8) that generate radical species and transformed garcinol (47) into the two corresponding xanthones 48 and 49.

In 1969, Atkinson et al. already reported this mechanism as a classical biomimetic oxidative coupling leading to xanthones [62]. They managed to perform this oxidative coupling using potassium ferricyanide (known as a radical donating reagent) with 2,3'-dihydroxybenzophenone, which is structurally close to maclurin (37).

Recently, our group has selectively converted guttiferone A(1) into the corresponding oxy-PPAP, 3,16-oxy-guttiferone, and maclurin (36) into norathyriol (31) using yeast [41] (๑ Fig. 9). This work involves an enzymatic reaction whose mechanism has not yet been defined. Enzymes might also be responsible for the biosynthesis of these derivatives in plants. In S. globulifera, symphonone $H(14)$ is strongly related to 7-epi-garcinol (16), which is probably the biosynthetic precursor of this oxy-PPAP.

\section{Biological Activities}

Phytochemical studies performed on the isolated metabolites of S. globulifera were extended to the study of their biological activities. Remarkably, a number of them were performed on protozoal or microbial diseases. The potent biological activities of these isolated molecules would confirm the traditional use of the plants ( $\odot$ Table 4 ).

\section{Antimalarial activity}

Among the exhaustive list of NPs possessing such activity, polyhydroxyxanthones, oxygenated, and prenylated xanthones, bixanthones and xantholignoids have been reported to potentially be a novel class of antimalarial agents with enhanced efficacy on multidrug resistant Plasmodium parasites. Seed shell extracts of S. globulifera contain three novel prenylated xanthones [gaboxanthone (21), globuliferin (22), symphonin (23)] and guttiferone A (1) ( $\bullet$ Fig. 1). Compound 1 possesses interesting antiplasmodial activities on P. falciparum W2 strains [21] ( Table 4). This first study on the potential of $S$. globulifera part extracts led to the exploration of the bark roots and the identification of 12 new PPAPs. The new PPAPs were evaluated for their antima- 

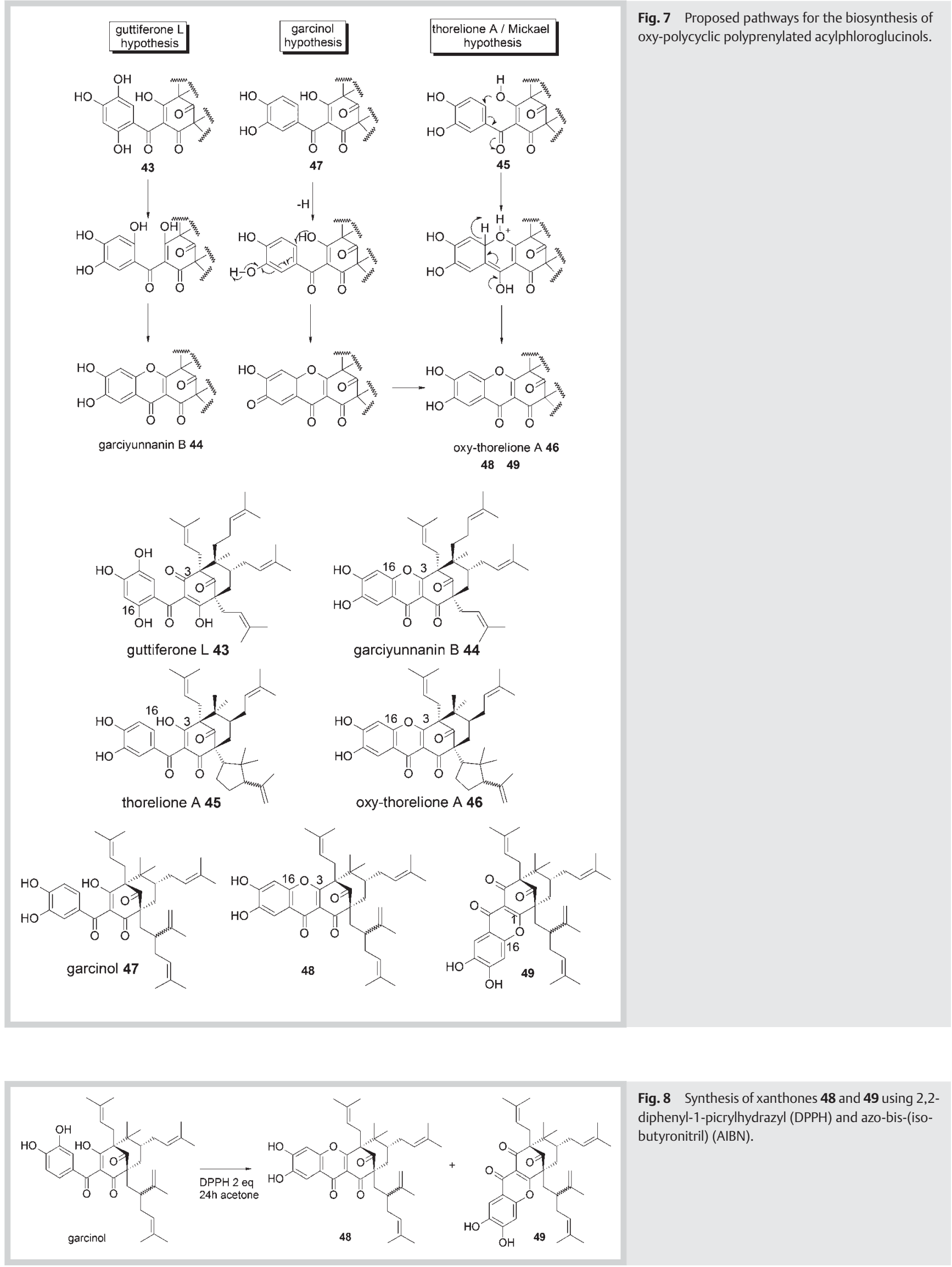


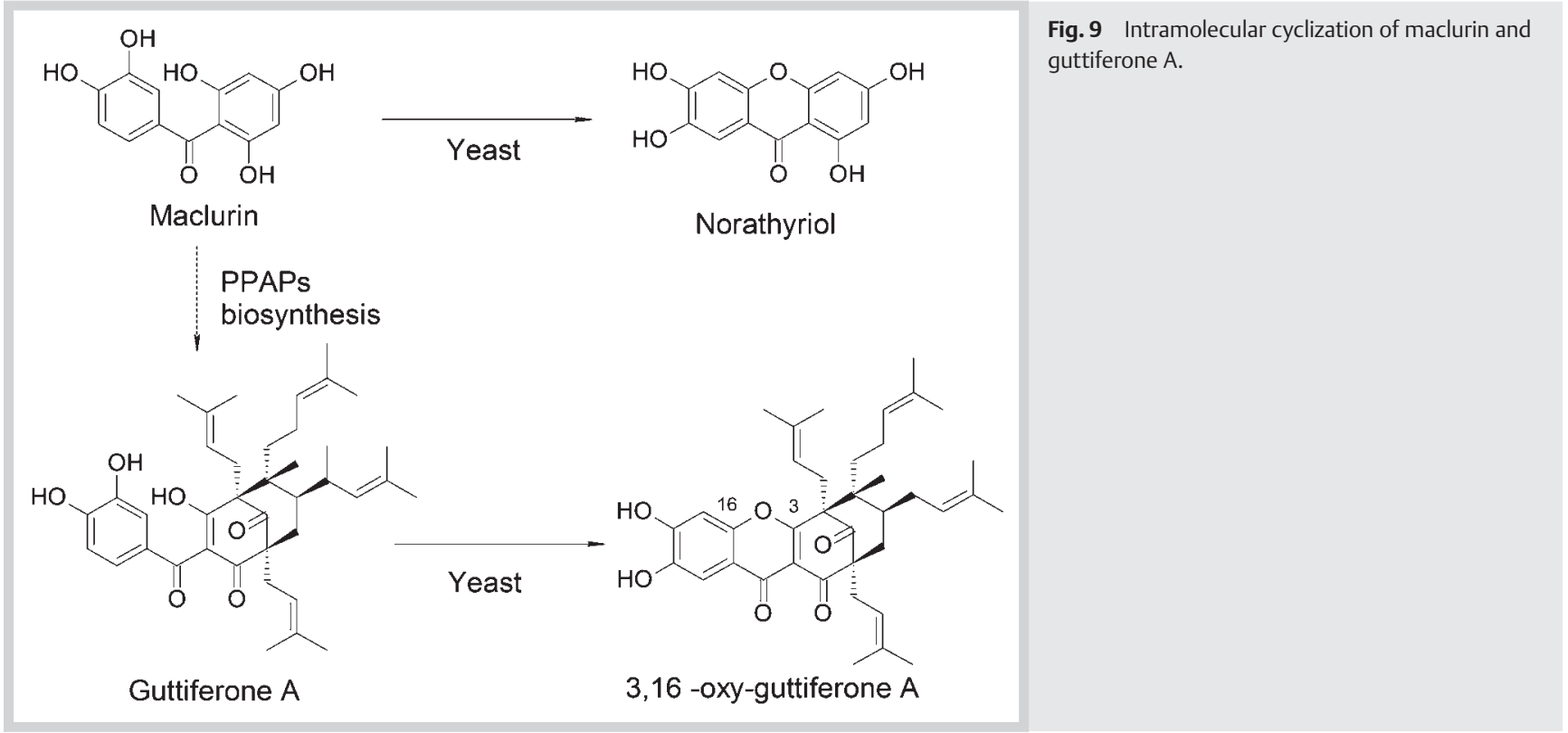

\begin{tabular}{|c|c|c|c|c|}
\hline \multicolumn{5}{|c|}{ Antiplasmodial activity } \\
\hline & & \multicolumn{2}{|c|}{$\mathrm{IC}_{50}(\mu \mathrm{M})$} & $\mathrm{IC}_{50}(\mu \mathrm{M})$ \\
\hline No. & Name & \multicolumn{2}{|c|}{ P. falciparum W2 } & P. falciparum FcB1 \\
\hline 1 & Guttiferone A & \multicolumn{2}{|c|}{3.17} & - \\
\hline 5 & 14-Deoxy7-epi-isogarcinol & \multicolumn{2}{|l|}{-} & 2.5 \\
\hline 6 & Symphonone A & \multicolumn{2}{|l|}{-} & 2.8 \\
\hline 7 & Symphonone B & \multicolumn{2}{|l|}{ - } & 3.3 \\
\hline 8 & Symphonone C & \multicolumn{2}{|l|}{-} & 2.6 \\
\hline 9 & 7-epi-Coccinone B & \multicolumn{2}{|l|}{ - } & 3.3 \\
\hline 10 & Symphonone D & \multicolumn{2}{|l|}{-} & 2.1 \\
\hline 11 & Symphonone E & \multicolumn{2}{|l|}{-} & 2.7 \\
\hline 12 & Symphonone F & \multicolumn{2}{|l|}{-} & 3.2 \\
\hline 13 & Symphonone G & \multicolumn{2}{|l|}{-} & 2.1 \\
\hline 14 & Symphonone $\mathrm{H}$ & \multicolumn{2}{|l|}{ - } & 3 \\
\hline 15 & Symphonone I & \multicolumn{2}{|l|}{-} & 6.7 \\
\hline 16 & 7-epi-Garcinol & \multicolumn{2}{|l|}{-} & 10.1 \\
\hline 17 & 7-epi-Isogarcinol & \multicolumn{2}{|l|}{-} & 3.2 \\
\hline 21 & Gaboxanthone & \multicolumn{2}{|l|}{3.53} & - \\
\hline 22 & Globuliferin & \multicolumn{2}{|l|}{1.29} & - \\
\hline 23 & Symphonin & \multicolumn{2}{|l|}{3.86} & - \\
\hline \multicolumn{5}{|c|}{ Antioxidant activity } \\
\hline \multicolumn{5}{|c|}{ \% Inhibition DPPH free radical } \\
\hline 21 & Gaboxanthone & \multicolumn{3}{|l|}{28} \\
\hline 22 & Globuliferin & \multicolumn{3}{|l|}{23} \\
\hline 23 & Symphonin & \multicolumn{3}{|l|}{54} \\
\hline 1 & Guttiferone A & \multicolumn{3}{|l|}{89} \\
\hline \multicolumn{5}{|c|}{ Antiparasitic activity } \\
\hline $\mathrm{IC}_{50} \mathrm{I}$ & & & & \\
\hline 1 & Guttiferone A & 0.16 & & \\
\hline 26 & Xanthone V1 & 1.4 & & \\
\hline Antin & um inhibitory concentratio & $\mathrm{g} / \mathrm{mL})$ & & \\
\hline & & Gram-pos & bacteria & Gram-negative bacteria \\
\hline & & S. aureus & B. subtilis & E. coli \\
\hline 18 & Globulixanthone C & 14.05 & 8.24 & Inactive \\
\hline 19 & Globulixanthone D & 8 & 12.5 & Inactive \\
\hline 20 & Globulixanthone E & 4.51 & 3.12 & Inactive \\
\hline- & Streptomycin & 6.25 & 0.85 & Inactive \\
\hline Cytot & $\mathrm{s} \mu \mathrm{g} / \mathrm{mL})$ & & & \\
\hline 24 & Globulixanthone A & 2.15 & & \\
\hline 25 & Globulixanthone B & 1.78 & & \\
\hline
\end{tabular}

Table 4 Biological activities of S. globulifera secondary metabolites. 
larial activity [22] (P. falciparum FcB1) and presented good to moderate $\mathrm{IC}_{50}$ values ranging from 2.1 to $10.1 \mu \mathrm{M}$ (○ Table 4).

\section{Antioxidant activity}

It has been proven that the Plasmodium infected red blood cells are under constant oxidative stress caused by exogenous reactive oxidant species and reactive nitrogen species produced by the immune system of the host and by the endogenous production of reactive oxidant species. Therefore, compounds able to exhibit both antiplasmodial and antioxidant activities are promising candidates as antimalarial agents. Thus, compounds 1, 21, 22, and 23 have been engaged in the free radical scavenging DPPH assay ( $\odot$ Table 4). The xanthones (21, 22, and 23) possess a limited antioxidant activity, while guttiferone A (1) has shown the best activity with $89 \%$ of inhibition of the DPPH radical.

\section{Antileishmanial activity}

The antiplasmodial activities of PPAPs and xanthones from $S$. globulifera mentioned before were confirmed, as they also possess interesting antileishmanial properties. Guttiferone A (1) is the lead compound of the series [69] ( $\odot$ Table 4). Furthermore, xanthone V1 (26) extracted from the leaves of S. globulifera also exhibits an interesting antiparasitic activity ( $\bigcirc$ Table 4 ). One of the major drawbacks of antileishmanial agents actually used in therapeutics is their substantial cytotoxicity towards the host cells due to an evident lack of selectivity. The relative cytotoxicity of compounds $\mathbf{1}$ and $\mathbf{2 6}$ was then evaluated towards normal rat skeletal muscles cells (L-6 cells). Interestingly, the aforementioned compounds have demonstrated a low cytotoxicity $\left(\mathrm{IC}_{50}=\right.$ 7.3 and $18 \mu \mathrm{M}$, respectively, 0 Table 4) allowing consideration for future development against the Leishmania donovani parasite.

\section{Antimicrobial activity}

The bioguided isolation from S. globulifera extracts that exerted antimicrobial activity led to the identification of globulixanthones C, D, and E (18-20). Compounds 18-20 were then tested for their antimicrobial effect on gram-positive (Staphylococcus aureus, Bacillus subtilis, Vibrio anguillarium) and gram-negative (E. coli) bacteria in an agar well diffusion assay [23]. As depicted in OTable 4, compounds $\mathbf{1 8 - 2 0}$ possess activities in the same range as streptomycin on gram-positive bacteria. However, they possess no activity on gram-negative bacteria, suggesting a selective killing. Biflavonoids $\mathbf{4 0}$ and $\mathbf{4 1}$ and xanthones $\mathbf{3 0}$ and $\mathbf{3 1} \mathrm{ex}-$ tracted from the stems of S. globulifera [27] have also shown good antimicrobial activity.

\section{Anticancer activity}

Natural products have played a consequent role in this course as it is estimated that $20 \%$ of anticancer drugs actually sold are derived from natural products. Root bark extracts of S. globulifera have been shown to possess interesting cytotoxic activity and the bioguided extraction led to the identification of globulixanthone A (24) and B (25) [24]. These two compounds were evaluated for their cytotoxic activity towards human epidermoid carcinoma of the nasopharynx (KB cell line, $\odot$ Table 4). Compounds 24 and $\mathbf{2 5}$ possess good properties, but no mechanistic studies have been run to date.

\section{Anti-HIV activity}

PPAPs from Clusia torresii (clusianone, 7-epi-clusianone, 18,19dihydroxyclusianone) have been proven to be potent anti-HIV agents that act by inhibiting gp120-sCD4 interaction. This mech- anism of action denotes a probable interference with the viral attachment to the CD4 membrane receptor implying an effect on infection. The MeOH extracts of S. globulifera have shown an activity in vitro toward HIV infected human cells (CEM-SS cells) [6]. The bioguided extraction has led to the identification of guttiferones $\mathrm{A}, \mathrm{B}, \mathrm{C}$, and $\mathrm{D}$ (compounds 1-4) as the active ingredients with an $\mathrm{EC}_{50}$ comprised between $1-10 \mu \mathrm{g} / \mathrm{mL}$, but no indications of a corresponding decrease of viral replication has been observed [6]. However, further mechanistic studies should be pursued.

\section{Anti-FAS activity}

Lipid biosynthesis is essential for the cell viability of all cellular living organisms and is notably ruled by FAS (fatty acid synthase) activity. As differences exist between the FAS of different organisms, FAS became an emerging target for diseases caused by microorganisms such as fungi or bacteria $[70,71]$. Two major types of FAS prevailed: type I exists in animal and fungi, and consists in a single multifunctional polypeptide [73], while type II exists in bacteria and plants, and comprises several enzymes, each of them assuring a step of the carbon chain elongation [72]. In a study aiming to identify new types of FAS inhibitors [31], ethanolic extracts of $S$. globulifera leaves were evaluated. The structural elucidation of the active compounds has led to the first identification of morelloflavone (39) and GB-2 (40), two original biflavonoids. Compounds $\mathbf{2 6}$ and $\mathbf{2 7}$ were active against FAS prepared from Saccharomyces cerevisiae with $\mathrm{IC}_{50}$ values of 30 and $23 \mu \mathrm{g} / \mathrm{mL}$, respectively.

\section{Anticholinesterase activity}

Acetylcholinesterase is a hydrolase responsible for the hydrolysis of acetylcholine to acetate and choline. It is found mainly in neuromuscular junctions and synapses, and plays a critical role in the transmission of nervous information. Its inhibition, leading to an accumulation of acetylcholine and the blockade of neurotransmission, is of importance notably for drug detoxification [74] or Alzheimer's disease treatment (improvement of cognitive function) [75]. Compound $\mathbf{1}$ isolated from S. globulifera is a potent inhibitor of acetylcholinesterase and butyrylcholinesterase $\left[\mathrm{IC}_{50}=\right.$ AChE $0.88 \mu \mathrm{M}$ (galanthamine $=0.5$ ) and $\mathrm{BChE}=2.77 \mu \mathrm{M}$ (galanthamine $=8.5)]($ O Table 4$)$.

\section{Conclusion \\ $\nabla$}

Interest in S. globulifera has been growing for several years for two reasons: the bioactivity of its secondary metabolites and a curious morphological diversification through times and sites. These differentiations have probably induced variations in the metabolome in order for the plant to adapt to the different African and American environments. A species able to rapidly acclimate to its environment by adapting its metabolome is an obvious rich source of new compounds and deserves to be studied in more detail. S. globulifera thus encloses various and complex secondary metabolites, such as PPAPs or flavonoid dimers. Moreover, the possible biogenesis of complex xanthones through oxidative ring closure from phloroglucinol derivatives is unprecedented. The traditional use by African or South American populations was then confirmed by biological assays, highlighting the impressive knowledge of nature gathered in those parts of the world, though still understudied. All the secondary metabolites isolated from S. globulifera have shown moderate to good antimi- 
crobial activities. Especially, guttiferone A, a major metabolite and lead compound, presents an impressive panel of diverse biological activities, and hemisynthetic derivatives have been proven to be potent antiparasitic agents [76]. Finally, S. globulifera could be illustrated as the perfect example of the paradigm of modern phytochemistry: a widespread source of complex metabolites with potent biological activities.

\section{Conflict of Interest}

$\nabla$

The authors report no conflicts of interest.

\section{References}

1 Harvey A. Natural products in drug discovery. Drug Discov Today 2008; 13: 894-901

2 Balick MJ, Mendelsohn R. Assessing the economic value of traditional medicines from tropical rain forests. Conser Biol 1992; 6: 128-130

3 Lopez A, Hudson JB, Towers GHN. Antiviral and antimicrobial activities of Colombian medicinal plants. J Ethnopharmacol 2001; 77: 189-196

4 Ssegawa P, Kasenene JM. Medicinal plant diversity and uses in the Sango bay area, Southern Uganda. J Ethnopharmacol 2007; 113: 521-540

5 Gupta MP, Solís PN, Calderón AI, Guionneau-Sinclair F, Correa M, Galdames C, Guerra C, Espinosa A, Alvenda GI, Robles G, Ocampo R. Medical ethnobotany of the Teribes of Bocas del Toro, Panama. J Ethnopharmacol 2005; 96: 389-401

6 Gustafson KR, Blunt JW, Munro MHG, Fuller RW, Mckee TC, Cardellina JH, Mcmahon JB, Cragg GM, Boyd MR. The guttiferones, HIV-Inhibitory Benzophenones from Symphonia globulifera, Garcinia livingstonei, Garcinia ovalifolia and Clusia rosea. Tetrahedron 1992; 48: 10093-10102

7 Kumar S, Sharma S, Chattopadhyay SK. The potential health benefit of polyisoprenylated benzophenones from Garcinia and related genera: ethno botanical and therapeutic importance. Fitoterapia 2013; 89: $86-125$

8 Dick CW, Abdul-Salim K, Bermingham E. Molecular systematic analysis reveals cryptic tertiary diversification of a widespread tropical rain forest tree. Am Nat 2003; 162: 691-703

9 Tropicos database, Missouri Botanical Garden. Available at http:// www.tropicos.org. Accessed October 1, 2014

10 Dick CW, Heuertz M. The complex biogeographic histrory of widespread tropical tree species. Evolution 2008; 62: 2760-2774

11 Lemée A. Flore de la Guyane française. Vol. 4. Paris: Lechevallier; $1952-$ 1956

12 Gill GE, Fowler RT, Mori SA. Pollination biology of Symphonia globulifera (Clusiaceae) in central French Guiana. Biotropica 1998; 30: 139-144

13 The International Plant Names Index 2013. Available at http://www.ipni.org. Accessed October 1, 2014

14 Budde KB, González-Martínez SC, Hardy OJ, Heuertz M. The ancient tropical rainforest tree Symphonia globulifera L. f. (Clusiaceae) was not restricted to postulated Pleistocene refugia in Atlantic Equatorial Africa. Heredity 2013; 111: 66-76

15 Akendengué B, Louis AM. Medicinal plants used by the Masango people in Gabon. J Ethnopharmacol 1994; 41: 193-200

16 Ajibesin K, Ekpo B, Bala D, Essien E, Adesanya S. Ethnobotanical survey of Akwa Ibom State of Nigeria. J Ethnopharmacol 2008; 115: 387-408

17 Lenta BN, Vonthron-Sénécheau C, Weniger B, Devkota KP, Ngoupayo J, Kaiser M, Naz Q Choudhary MI, Tsamo E, Sewald N. Leishmanicidal and cholinesterase inhibiting activities of phenolic compounds from Allanblackia monticola and Symphonia globulifera. Molecules 2007; 12: 1548-1557

18 Coelho-Ferreira M. Medicinal knowledge and plant utilization in an Amazonian coastal community of Marudá, Pará State (Brazil). J Ethnopharmacol 2009; 126: 159-175

19 Kadiri $A B$. Evaluation of medicinal herbal trade (Paraga) in Lagos State of Nigeria. Ethno Leaflets 2008; 12: 677-681

20 Ciochina $R$, Grossman RB. Polycyclic polyprenylated acylphloroglucinols. Chem Rev 2006; 106: 3963-3986

21 Ngouela S, Lenta BN, Noungoue DT, Ngoupayo J, Boyom FF, Tsamo E, Gut J, Rosenthal PJ, Connolly JD. Anti-plasmodial and antioxidant activities of constituents of the seed shells of Symphonia globulifera Linn f. Phytochemistry 2006; 67: 302-306
22 Marti G, Eparvier V, Moretti C, Prado S, Grellier P, Hue N, Thoison O, Delpech B, Guéritte F, Litaudon M. Antiplasmodial benzophenone derivatives from the root barks of Symphonia globulifera (Clusiaceae). Phytochemistry 2010; 71: 964-974

23 Nkengfack AE, Mkounga P, Meyer M, Fomum ZT, Bodo B. Globulixanthones C, D and E: three prenylated xanthones with antimicrobial properties from the root bark of Symphonia globulifera. Phytochemistry 2002; 61: 181-187

24 Nkengfack AE, Mkounga P, Fomum ZT, Meyer M, Bodo B. Globulixanthones $A$ and $B$, two new cytotoxic xanthones with isoprenoid groups from the root bark of Symphonia globulifera. J Nat Prod 2002; 65: 734736

25 Bayma JC, Arruda MSP, Neto MS. A prenylated xanthone from the bark of Symphonia globulifera. Phytochemistry 1998; 38: 1159-1160

26 Locksley HD, Moore I, Scheinmann F. Extractives from Guttiferae. Part II. The isolation and structure of four polyhydroxyxanthones in Symphonia globulifera L. J Chem Soc C 1966; 430-432

27 Mkounga P, Fomum ZT, Meyer M, Bodo B, Nkengfack AE. Globulixanthone $\mathrm{F}$, a new polyoxygenated xanthone with an isoprenoid group and two antimicrobial biflavonoids from the stem bark of Symphonia globulifera. Nat Prod Comm 2009; 4: 803-808

28 Locksley HD, Moore I, Scheinmann F. Extractives from Guttiferae. Part III. The isolation and structure of symphoxanthone and globuxanthone from Symphonia globulifera L. J Chem Soc C 1966; 2186-2190

29 Locksley HD, Moore I, Scheinmann F. Extractives from Guttiferae. Part IV. Isolation and structure of ugaxanthone and $\mathrm{M}$ barraxanthone from Symphonia globulifera L. J Chem Soc C 1966; 2265-2269

30 Locksley HD, Moore I, Scheinmann F. Extractives from guttiferae-VI: the significance of maclurin in xanthone biosynthesis. Tetrahedron 1967; 23: 2229-2234

31 Li XC, Joshi AS, ElSohly HN, Khan SI, Jacob MR, Zhang Z, Khan IA, Ferreira $D$, Walker LA, Broedel SE jr., Raulli RE, Cihlar RL. Fatty acid synthase inhibitors from plants: isolation, structure elucidation, and SAR studies. J Nat Prod 2002; 65: 1909-1914

32 Hamed W, Brajeul S, Mahuteau-Betzer F, Thoison O, Mons S, Delpech B, Nguyen VH, Sévenet T, Marazano C. Oblongifolins A-D, polyprenylated benzoylphloroglucinol derivatives from Garcinia oblongifolia. J Nat Prod 2006; 69: 774-777

33 Huang SX, Feng C, Zhou Y, Xu G, Han QB, Qiao CF, Chang DC, Luo KQ Xu $H X$. Bioassay-guided isolation of xanthones and polycyclic prenylated acylphloroglucinols from Garcinia oblongifolia. J Nat Prod 2009; 72: 130-135

34 Xu G, Feng C, Zhou Y, Han QB, Qiao CF, Huang SX, Chang DC, Zhao QS, Luo $K Q, X u H X$. Bioassay and ultraperformance liquid chromatography/ mass spectrometry guided isolation of apoptosis-inducing benzophenones and xanthone from the pericarp of Garcinia yunnanensis Hu. J Agric Food Chem 2008; 56: 11144-11150

35 Yang H, Figueroa M, To S, Baggett S, Jiang B, Basile MJ, Weinstein IB, Kennelly EJ. Benzophenones and biflavonoids from Garcinia livingstonei fruits. J Agric Food Chem 2010; 58: 4749-4755

36 Acuña UM, Figueroa M, Kavalier A, Jancovski N, Basile MJ, Kennelly EJ. Benzophenones and biflavonoids from Rheedia edulis. J Nat Prod 2010; 73: 1775-1779

37 Williams RB, Hoch J, Glass TE, Evans R, Miller JS, Wisse JH, Kingston DG. A novel cytotoxic guttiferone analogue from Garcinia macrophylla from the Suriname rainforest. Planta Med 2003; 69: 864-866

38 Merza J, Mallet S, Litaudon M, Dumontet $V$, Séraphin D, Richomme P. New cytotoxic guttiferone analogues from Garcinia virgata from New Caledonia. Planta Med 2006; 72: 87-89

39 Pereira IO, Marques MJ, Pavan AL, Codonho BS, Barbiéri CL, Beijo LA, Doriguetto AC, D'Martin EC, dos Santos MH. Leishmanicidal activity of benzophenones and extracts from Garcinia brasiliensis Mart. Fruits. Phytomedicine 2010; 17: 339-345

40 Sang S, Liao CH, Pan MH, Rosen RT, Lin-Shiau SY, Lin JK, Ho CT. Chemical studies on antioxidant mechanism of garcinol: analysis of radical reaction products of garcinol with peroxyl radicals and their antitumor activities. Tetrahedron 2002; 58: 10095-10102

41 Fromentin Y, Grellier P, Wansi JD, Lallemand MC, Buisson D. Yeast-mediated xanthone synthesis through oxidative intramolecular cyclization. Org Lett 2012; 14: 5054-5057

42 Ren Y, Yuan C, Chai HB, Ding Y, Li XC, Ferreira D, Kinghorn AD. Absolute configuration of (-)-gambogic acid, an antitumor agent. J Nat Prod 2011; 74: 460-463 
43 Zhang X, Li X, Sun H, Wang X, Zhao L, Gao Y, Liu X, Zhang S, Wang Y, Yang $Y$, Zeng S, Guo $Q$ You $Q$. Garcinia xanthones as orally active antitumor agents. J Med Chem 2013; 56: 276-292

44 Baslas RK, Kumar P. Isolation and characterization of biflavanone and xanthones in the fruits of Garcinia xanthochymus. Acta Ciencia Indica Chemistry 1981; 7: 31-34

45 Bittrich V, Nascimento-Junior JE, Amaral MCE, Nogueira PC. The anther oil of Symphonia globulifera L.f. (Clusiaceae). Biochem Syst Ecol 2013; 49: 131-134

46 Atkinson JE, Gupta P, Lewis JR. Benzophenone participation in xanthone biosynthesis (Gentianaceae). Chem Comm 1968; 1386-1387

47 Camm EL, Towers GHN. Phenylalanine ammonia lyase. Phytochemistry 1973; 12: 961-973

48 Sutter A, Grisebach H. Biosynthesis of flavonoids - XXXIV. Occurrence of the "NIH-SHIFT" in flavonoid biosynthesis. Phytochemistry 1969; 8: 101-106

49 Ali MA, Kagan J. The biosynthesis of flavonoid pigments: on the incorporation of phloroglucinol and phloroglucinol cinnamate into rutin in Fagopyrum esculentum. Phytochemistry 1974; 13: 1479-1482

50 Schröder J, Raiber S, Berger T, Schmidt A, Schmidt J, Soares-Sello AM, Bardshiri E, Strack D, Simpson TJ, Veit M, Schröder G. Plant polyketide synthases: a chalcone synthase-type enzyme which performs a condensation reaction with methylmalonyl-CoA in the biosynthesis of Cmethylated chalcones. Biochemistry 1998; 37: 8417-8425

51 Li X, Park NI, Xu H, Woo SH, Park CH, Park SU. Differential expression of flavonoid biosynthesis genes and accumulation of phenolic compounds in common buckwheat (Fagopyrum esculentum). J Agric Food Chem 2010; 58: 12176-12181

52 Halbwirth H, Puhl I, Haas U, Jezik K, Treutter D, Stich K. Two-phase flavonoid formation in developing strawberry (Fragaria $\mathrm{x}$ ananassa) fruit. J Agric Food Chem 2006; 54: 1479-1485

53 Yamaguchi LF, Kato MJ. Diurnal and seasonal changes in biflavonoids biosynthesis in Araucaria angustifolia needles. Glob J Biochem 2012; 3: 9-12

54 Molyneux RJ, Waiss ACJ, Haddon WF. Oxidative coupling of apigenin. Tetrahedron 1970; 26: 1409-1416

55 Beerhues L, Liu B. Biosynthesis of biphenyls and benzophenones - evolution of benzoic acid-specific type III polyketide synthases in plants. Phytochemistry 2009; 70: 1719-1727

56 Fujita M, Inoue T. Biosynthesis of mangiferin in Anemarrhena asphodeloides: intact incorporation of C6-C3 precursor into xanthone. Tet Lett 1977; 51: 4503-4506

57 Fujita M, Inoue T. Further studies on the biosynthesis of mangiferin in Anemarrhena asphodeloides: hydroxilation of the shikimate-derived ring. Phytochemistry 1981; 20: 2183-2185

58 Nualkaew N, Morita H, Shimokawa Y, Kinjo K, Kushiro T, De-Eknamkul W, Ebizuka Y, Abe I. Benzophenone synthase from Garcinia mangostana L. pericarps. Phytochemistry 2012; 77: 60-69

59 Masters KS, Bräse S. Xanthones from fungi, lichens, and bacteria: the natural products and their synthesis. Chem Rev 2012; 112: 3717-3776

60 Hill JG, Nakashima TT, Vederas JC. Fungal xanthone biosynthesis. Distribution of acetate-derived oxygens in ravenelin. J Am Chem Soc 1982; 104: $1745-1748$
61 Peters S, Schmidt W, Beerhues L. Regioselective oxidative phenol couplings of 2, 3',4, 6-tetrahydroxybenzophenone in cell cultures of Centaurium erythraea RAFN and Hypericum androsaemum L. Planta 1998; 204: 64-69

62 Atkinson JE, Lewis JR. Oxidative coupling. Part VII. Biogenetic type synthesis of naturally occurring xanthones. J Chem Soc C 1969; 281-287

63 Adam P, Arigoni D, Bacher A, Eisenreich W. Biosynthesis of hyperforin in Hypericum perforatum. J Med Chem 2002; 45: 4786-4793

64 Boubakir Z, Beuerle T, Liu B, Beerhues L. The first prenylation step in hyperforin biosynthesis. Phytochemistry 2005; 66: 51-57

65 Karppinen K, Hokkanen J, Tolonen A, Mattila S, Hohtola A. Biosynthesis of hyperforin and adhyperforin from amino acid precursors in shoot cultures of Hypericum perforatum. Phytochemistry 2007; 68: 10381045

66 George JH, Hesse MD, Baldwin JE, Adlington RM. Biomimetic synthesis of polycyclic polyprenylated acylphloroglucinol natural products isolated from Hypericum papuanum. Org Lett 2010; 12: 3532-3535

67 Nguyen LTT, Nguyen HT, Barbič M, Brunner G, Heilmann J, Pham HD, Nguyen DM, Nguyen LHD. Polyisoprenylated acylphloroglucinols and a polyisoprenylated tetracyclic xanthone from the bark of Calophyllum thorelii. Tet Lett 2012; 53: 4487-4493

68 Sang S, Liao CH, Pan MH, Rosen RT, Lin-Shiau SY, Lin JK, Ho CT. Chemical studies on antioxidant mechanism of garcinol: analysis of radical reaction products of garcinol and theirs antitumor activities. Tetrahedron 2001; 57: 9931-9938

69 Lenta BN, Vonthron-Sénécheau C, Fongang Soh R, Tantangmo F, Ngouela $S$, Kaiser $M$, Tsamo E, Anton $R$, Weniger B. In vitro antiprotozoal activities and cytotoxicity of some selected Cameroonian medicinal plants. J Ethnopharmacol 2007; 11: 8-12

70 Wang J, Hudson R, Sintim HO. Inhibitors of fatty acid synthesis in prokaryotes and eukaryotes as anti-infective, anticancer and anti-obesity drugs. Future Med Chem 2012; 4: 1113-1151

71 Zhao XJ, McElhaney-Feser GE, Sheridan MJ, Broedel SE JR, Cihlar RL. Avirulence of Candida albicans FAS2 mutants in a mouse model of systemic candidiasis. Infect Immun 1997; 65: 829-832

72 Liu H, Liu JY, Wu X, Zhang JT. Biochemistry, molecular biology, and pharmacology of fatty acid synthase, an emerging therapeutic target and diagnosis/prognosis marker. Int J Biochem Mol Biol 2010; 1: 69-89

73 Smith $S$. The animal fatty acid synthase: one gene, one polypeptide, seven enzymes. FASEB J 1994; 8: 1248-1259

74 Lin SK. Rapid detoxification of benzodiazepine or Z-drugs dependence using acetylcholinesterase inhibitors. Med Hypotheses 2014; 83: 108110

75 Silva T, Reis J, Teixeira J, Borges F. Alzheimer's disease, enzyme targets and drug discovery struggles: from natural products to drug prototypes. Ageing Res Rev 2014; 15: 116-145

76 Fromentin Y, Gaboriaud-Kolar N, Lenta BN, Wansi JD, Buisson D, Mouray E, Grellier P, Loiseau PM, Lallemand MC, Michel S. Synthesis of novel guttiférone A derivatives: in-vitro evaluation toward Plasmodium falciparum, Trypanosoma brucei and Leishmania donovani. Eur J Med Chem 2013; 65: 284-294 